\title{
UPAYA GURU PENDIDIKAN AGAMA ISLAM (PAI) DALAM MENINGKATKAN KESADARAN BERIBADAH SISWA KLAS VIII DI SMPN 1 BANYAKAN KABUPATEN KEDIRI
}

\author{
Binti Masruroh \\ Program Pascasarjana Institute Agama Islam Tribakti Kediri
}

\begin{abstract}
Abstrak
Unsur penting untuk meningkatkan mutu pendidikan adalah dengan cara membenahi sistem pengelolaan sekolah, administrasi sekolah, kedisiplinan, dan termasuk upaya guru meningkatkan kesadaran beribadah siswa. Karena itu peran guru agama Islam dalam hal ini sangat menentukan. Penelitian ini dilakukan di Sekolah Menengah Pertama (SMP) Negeri I Banyakan Kediri.

fokus penelitian ini meliputi, Bagaimana upaya guru pendidikan agama islam (pai) dalam meningkatkan kesadaran beribadahsiswa klas viii di SMPN 1 Banyakan Kabupaten Kediri. 2. Apa faktor pendukung dan penghambat Pendidikan Agama Islam (PAI) dalam berupaya meningkatkan kesadaran beribadah siswa di Sekolah Menengah Pertama (SMP) Negeri I Banyakan Kab. Kediri.

Peneitian ini menggunakan pendekatan penelitian kualitatif. Sementara penggalian datanya menggunakan metode observasi, interview, dan dokumentasi. Sedangkan analisi data dilakukan dengan tiga tahap yakni reduksi data, display data, dan penarikan kesimpulan.

Hasil penelitian ini memberikan penjelasan bahwa upaya guru pendidikan agama islam dalam meningkatkan kesadaran beribadah siswa di SMPN 1 Banyakan Kab. Kediri sangat beragama. Di antaranya dari unsur keteladanan, pembiasaan, memberikan motivasi, memberi nasehat dan mengajak secara langsung yang bersangkutan, dan menciptakan suasana yang religius di sekolah. Semua yang dilakukan di sekolah menggunakan pendekatan yang humanis. Sementara faktor Pendukung dan Penghambat bagi Guru Pendidikan Agama Islam dalam Upaya Meningkatkan Kesadaran Beribadah Pada Siswa di SMPN 1 Banyakan Kab. Kediri terdiri dari, kesadaran siswa sendiri, fasilitas ibadah yang cukup memaadahi, koordinasi yang baik dengan berbagai pihak, salah satu ekstra kurikuler, yaitu Sejarah Kebudayaan Islam (SKI). Kemudian faktor penghambat meliputi, kelengkapan sarana \& prasarana media pembelajaran praktek ibadah yang sangat minim, kesadaran siswa yang kompleks dan beragam, dan waktu pembelajaraan pendidikan agama Islam yang sangat terbatas.
\end{abstract}

Kata Kunci: Upaya Guru, Kesadaran Beribadah Siswa,

\section{A. Konteks Penelitian}

Pendidikan secara umum merupakan sebuah interaksi sosial antara dua orang atau lebih, baik bersifat formal, non-formal maupun informal. Untuk mendapatkan pendidikan yang berkualitas, maka dibutuhkan input pendidikan yang baik, salah satunya adalah input sumber daya manusia (SDM) dan sumber daya insani (SDI), baik peserta didik, pendidik, tenaga kependidikan dan pengelola kependidikan.
Pendidikan nasional berfungsi mengembangkan dan membentuk watak serta peradaban bangsa, bertujuan untuk mengembangkan potensi perserta didik agar menjadi manusia yang beriman dan bertaqwa terhadap Tuhan Yang Maha Esa.

Tujuan pendidikan nasional ditekankan kembali dalam rumusan arah kebijakan pendidikan nasional, yaitu mengembangkan kualitas manusia sedini mungkin secara terarah, 
terpadu dan menyeluruh melalui berbagai upaya proaktif dan kreatif oleh seluruh komponen bangsa agar generasi muda dapat berkembang secara optimal. Rumusan tersebut sesuai dengan penjelasan dalam Undang-undang Dasar 1945 yang menegaskan bahwa pemerintah mengusahakan dan menyelenggarakan suatu sistem pengajaran nasional yang diatur dengan Undang-undang ${ }^{1}$.

Sebagai pemegang amanat dan sebagai salah satu pelaksana pendidikan agama Islam, guru tidak hanya memberikan pendidikan ilmiah,akan tetapi hendaknya tugas guru merupakan kelanjutan dan sinkron dengan tugas orang tua, yang juga merupakan tugas guru Pendidikan Agama Islam (PAI), yaitu dengan memberikan pendidikan yang berwawasan manusia seutuhnya ${ }^{2}$.

Dengan demikian dapat disimpulkan bahwa guru merupakan substansi dari orang tua di sekolah. Dalam meningkatkan kesadaran beribadah pada semua siswa, tentu peran serta guru Pendidikan Agama Islam (PAI) sangat menunjang. Di lingkungan sekolah seorang guru sangat mempunyai peranan penting dalam peningkatan kesadaran beribadah siswa, selain harus menyampaikan materi pelajaran, guru yang setiap hari bergaul dengan siswasiswanya mengemban tugas sebagai pendidik yang berkewajiban membantu pertumbuhan dan perkembangan siswa serta meningkatkan keimannan dan ketaqwaan siswa kepada Allah swt.bantuan itu tidak sekedar aspek intelektual, akan tetapi meliputi aspek spiritual yang berfungsi sebagai upaya pendekatan diri pada Allah swt. melalui ibadah.

Alasan peneliti memilih lokasi di Sekolah Menengah Pertama (SMP) Negeri I Banyakan Kediri adalah karena sekolah tersebut merupakan sekolah yang dianggap favorit dan terkemukaoleh masyarakat di Kecamatan BanyakanKab. Kediri yang kesadaran beribadah cukup tinggi.Hal ini dapat diketahui berdasarkan pengamatan peneliti bahwa sebagian siswa-siswi rajin dalam melaksanakan ibadah shalat, puasa hariSenin \&

1 Undang-undang Dasar 1945, (Surabaya: Karya Utama, 2009), hlm. 26.

2 Hery Noer Aly, IImu Pendidikan Islam, hlm. 95.
Kamis, bakti sosial, Pondok Ramadhan, Shalat Idhul Fitri, Shalat Idhul Adha(Qurban), dan jama'ah shalat maktubah di Musholla Sekolah Menengah Pertama (SMP) Negeri I Banyakan Kab. Kediri.

Pelaksanakan Pendidikan Agama Islam di Sekolah Menengah Pertama (SMP) Negeri I Banyakan Kab. Kediri lebih ditekankan pada praktik amaliyah, diantaranya "Shalat Dhuha, Shalat Jama'ah Dhuhur, Shalat Jum'at, dan Ashar' serta kegiatan-kegiatan keagamaan lainya yang diadakan di sekolah. Demikian juga ditunjang dengan adanya sarana pembentuk kepribadian siswa, yaitu adanya “Kantin Kejujuran"untuk melatih sikap dan perilaku siswa untuk berlaku jujur, kemudian bersalaman dengan para guru dan guru kelas, setiap hari, baik ketika masuk sekolah pagi dan siang (sore) ketika pulang sekolahdengan formasi berbaris rapi, kemudian bersalaman dengan guru satu persatu (dengan cium tangan) para guru dan ucapan salam.

Dari uraian diatas jelaslah bahwa mewujudkan kesadaran beribadah siswa sangatlah penting, karena sebagai jalan utama untuk taqarrub(dekat) kepada Allah swt., maka penulis tertarik untuk mengambil judul "Upaya GuruPendidikan Agama Islam (PAI) dalam Meningkatkan Kesadaran Beribadah SiswadiSekolah Menengah Pertama (SMP) Negeri I BanyakanKab. Kediri”.

\section{B. Fokus Penelitian}

Berdasarkan konteks penelitian diatas, maka penulis akan menjadikan fokus penelitian sebagai berikut :

1. Bagaimana Upaya GuruPendidikan Agama Islam (PAI)dalam Meningkatkan Kesadaran Beribadah SiswadiSekolah Menengah Pertama (SMP) Negeri I Banyakan Kab. Kediri ?

2. Apa faktor pendukung dan penghambat Pendidikan Agama Islam (PAI) dalam berupaya meningkatkan kesadaran beribadah siswa di Sekolah Menengah Pertama (SMP) Negeri I Banyakan Kab. Kediri ? 


\section{Tujuan Penelitian}

1. Untuk menjelaskan Upaya GuruPendidikan Agama Islam (PAI)dalam Meningkatkan Kesadaran Beribadah SiswadiSekolah Menengah Pertama (SMP) Negeri I Banyakan Kab. Kediri

2. Untuk mengkaji faktor pendukung dan penghambat Pendidikan Agama Islam (PAI) dalam berupaya meningkat kesadaran beribadah siswa di Sekolah Menengah Pertama (SMP) Negeri I Banyakan Kab. Kediri.

\section{Metode Penelitian}

Dalam penelitian ini penulis menggunakan pendekatan deskriptif kualitatif. Pendekatan ini digunakan sebagai prosedur penelitian yang menghasilkan data deskriptif berupa kata-kata tertulis atau lisan dari orang-orang dan perilaku yang dapat diamati. ${ }^{3}$

Kemudian peneliti berusaha mengungkap gejala-gejala kejadian secara menyeluruh yang sesuai dengan konteks penelitian (holistic kontekstual) melalui pengumpulan data dari latar alami dengan memanfaatkan diri sebagai instrumen kunci. ${ }^{4}$

Adapun jenis penelitian yang dilakukan dalam penelitian ini adalah studi kasus, yaitu merupakan penelitian tentang subyek penelitian yang berkenaan dengan suatu fase spesifik atau khas dari keseluruhan personalitas. ${ }^{5}$

Jadi dalam penelitian ini peneliti akan meneliti kekhususan dari subyek peneliti, terutama upaya guru pendidikan agama Islam dalam meningkatkan kesadaran beribadah pada siswa di SDN Nambakan Ringinrejo Kediri sebagai prosedur penelitian untuk menghasilkan data deskriptif berupa kata-kata tertulis.

3 Lexy J. Moleong, Metodologi Penelitian Kualitatif (Bandung : PT Remaja Rosdakarya, 1998), h. 3.

4 Tim Penyusun Buku Pedoman Penulisan Karya IImiah STAIN Kediri, Pedoman Penulisan Karya IImiah (Kediri:STAIN Kediri,2005), h. 63.

5 Moh. Nazir, Metode Penelitian (Jakarta : Graha Indonesia, 2005), h. 57.

\section{Lokasi dan Obyek Penelitian}

Penelitian ini dilaksanakan di SDN Nambakan Ringinrejo Kediri sebagai obyek penelitian dengan asumsi bahwa SD tersebut adalah salah satu SD terkemuka di Ringinrejo yang ternyata siswanya juga memiliki kesadaran beribadah yang baik hal ini terbukti dari rajin melaksanakan shalat dhuha dan shalat dzuhur berjamaah.

\section{Kerangka Teori}

\section{Guru Agama Islam}

Pengertian guru secara umum adalah semua orang yang berwenang dan bertanggungjawab serta pemegang amanat dengan melaksanakan proses pembelajaran dalam membimbing dan membina anak didik baik secara individual maupun klasikal di sekolah maupun di luar sekolah.

Secara umum, pendidik adalah orang yang memiliki tanggungjawab untuk mendidik. Sedangkan guru Pendidikan Agama Islam adalah orang yang bertanggungjawab terhadap upaya perkembangan jasmani dan rohani siswa agar mencapai tingkat kedewasaan sehingga siswa mampu menunaikan tugas-tugas kemanusiaannya (baik sebagai khalifah di bumi maupun ibadah) sesuai dengan nilai-nilai ajaran Islam. ${ }^{6}$

\section{Fungsi dan Peran Guru Pendidikan Agama Islam}

Sebagai pelaksana pendidikan, guru mempunyai fungsi dan peran sebagai berikut: a) Peran guru sebagai pembimbing, yaitu peran yang sangat berkaitan dengan praktik keseharian. Untuk dapat menjadi seorang pembimbing, guru harus mampu memperlakukan siswa dengan menghormati dan menyayangi (mencintai). 2) Peran guru sebagai model dan contoh (uswah), dalam aktivitas dan proses pembelajaran, termasuk pembelajaran pendidikan agama Islam, semua tutur kata, sikap, cara berpakaian, penampilan, cara mengajar, dan gerak-gerik serta perilaku

6 Samsul Nizar, Filsafat Pendidikan Islam, (Jakarta: Ciputat Pers, 2002), hlm. 41 - 42 
guru selalu diperhatikan oleh siswa dan sulit dihilangkan dalam ingatan setiap siswa. Karakteristik guru selalu dijadikan cermin oleh siswa-siswanya. 3) Peran guru sebagai penasihat, seorang guru memiliki jalinan ikatan batin (emosional) dengan siswa yang diajarnya. Dalam hubungan ini pendidik berperan aktif sebagai penasihat, yaitu berperan bukan hanya sekedar menyampaikan materi pelajaran, akan tetapi juga harus mampu memberi nasihat bagi siswa yang membutuhkanya, baik diminta

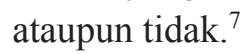

\section{Syarat-Syarat Guru Agama Islam}

Menurut Soejono yang dikutip oleh Ahmad Tafsir, menyatakan bahwa syarat guru Pendidikan Agama Islam (PAI) : Tentang umur, harus sudah dewasa, Tentang kesehatan, harus sehat jasmani dan rohani, Tentang kemampuan mengajar, ia harus ahli (profesional), Harus berkesusilaan dan berdedikasi tinggi. ${ }^{8}$

\section{Tugas dan Tanggungjawab Guru Agama Islam}

Menurut Roestiyah NK. sebagaimana yang dikutip oleh Syaiful Bahri Djamarah menyatakan bahwa guru dalam mendidik anak didik bertugas untuk:

a. Menyerahkan kebudayaan (kebiasaan yang baik) kepada anak didik (siswa) berupa kepandaian, kecakapan dan pengalamanpengalaman.

b. Membentuk kepribadian siswa yang harmonis, sesuai cita-cita yang diharapkan untul masa depanya.

c. Menyiapkan anak menjadi warga Negara yang baik sesuai dengan Undang-undang Nomor 20 Tahun 2003 tentang Sisdiknas.

d. Sebagai perantara dalam belajar.

e. Guru sebagai pembimbing, untuk membawa anak didik kearah kedewasaan.

f. Guru sebagai penghubung antara sekolah dan masyarakat.

7 Mukhtar, Desain Pembelajaran Pendidikan Agama Islam, (Jakarta: Misaka Gazila, 2003), hlm. 93 -96

8 Ahmad Tafsir, Ilmu Pendidikan Dalam Perspektif Islam, (Bandung: Remaja Rosda Karya, 2004), hlm. 80 g. Sebagai penegak disiplin.

h. Guru sebagai administrator dan manager.

i. Pekerjaan guru sebagai suatu profesi.

j. Guru sebagai perencana kurikulum.

k. Guru sebagai pemimpin (guidance worker).

1. Guru sebagai sponsor dalam kegiatan anak-anak. ${ }^{9}$

\section{Kesadaran Manusia}

Arti kesadaran menurut bahasa adalah hal yang dirasakan (dialami) seseorang. ${ }^{10}$ Kesadaran adalah keinsafan akan suatu perbuatan. Sadar artinya merasa (ingat) kembali (dari pingsannya), siuman, bangun (dari tidur), ingat, tahu dan mengerti. Misalnya rakyat telah sadar akan politik, seorang hamba telah sadar ibadah, jadi kesadaran adalah hati (pikiran) yang telah terbuka untuk melakukan suatu pekerjaan. ${ }^{11}$

Dari penjelasan diatas dapat ditarik suatu kesimpulan, bahwa kesadaran adalah hal yang dirasakan (dialami) seseorang dimana hati atau pikirannya telah terbuka untuk melakukan suatu pekerjaan disebabkan rangsangan eksternal maupun internal. Dalam hal ini seseorang telah terbuka hatinya untuk melaksanakan ibadah karena telah merasakan betapa pentingnya ibadah tersebut.

\section{Perkembangan Kesadaran}

Salah satu kelebihan manusia sebagai makhluk Allah swt.adalah dia dianugerahi fitrah (perasaan, potensi dan kemampuan) untuk mengenal Allah dan melakukan ajaran-Nya. Dengan kata lain, manusia dikaruniai insting religius (naluri beragama). Jiwa beragama atau kesadaran beragama merujuk kepada aspek rohaniah individu yang berkaitan dengan keimanan kepada Allah swt. yang direfleksikan

9 Syaiful Bahri Djamarah, Guru dan Anak Didik dalam Interaktif Edukatif, hlm. 38 - 39

10 Departemen Pendidikan dan Kebudayaan, Kamus Besar Bahasa Indonesia, hlm. 856

11 Ahmad Mustofa, IImu Budaya Dasar, (Bandung : Pustaka Setia, 1996), hlm. 139 
ke dalam peribadatan kepada-Nya. ${ }^{12}$

\section{Ibadah}

Ibadah berasal dari kata 'abdartinya adalah "pelayan" atau"budak". Dengan demikiaanibadat berarti "penghambaan" dan "perbudakan"13 Dalam perspektif bahasa, "ibadah" memiliki arti taat atau patuh atau menurut. ${ }^{14}$ Adapun menurut istilah, kata "ibadah" adalah penghambaan diri yang sepenuh-penuhnya untuk mencapai keridhoan Allah swt. dan mengharap mendapat pahala Allah swt. di akhirat. ${ }^{15}$

Dari definisi tersebut dapat disimpulkan bahwa ibadah itu tidaklah terbatas seperangkat ritual yang dikenal luas dengan sebutan rukun Islam, akan tetapi ibadah itu adalah mencakup seluruh aspek baik itu hubungan manusia dengan sang pencipta, manusia dengan manusia maupun manusia dengan lingkungan untuk mencapai keridhoan Allah SWT.

\section{Pentingnya Manusia Beribadah}

Secara umum ibadah berarti bakti manusia kepada Allah swt. karena didorong dan dibangkitkan oleh akidah tauhid, sehingga ibadah menjadi tujuan hidup manusia. Menyembah Allah swt. memusatkan penyembahan kepada Allah semata-mata, tidak ada yang disembah dan mengabdikan diri kecuali kepada-Nya saja. Semua itu dilakukan dengan kesadaran, baik orang-seorang dalam masyarakat, maupun secara bersama-sama. ${ }^{16}$

Dengan demikian, beribadah merupakan naluri yang menjadi fitrah manusia untuk mencari sesuatu yang sempurna tanpa cela,

12 Syamsu Yusuf, Psikologi Perkembangan Anak dan Remaja, (Bandung : Remaja Rosdakarya,2000), hlm. 136

13 Abul A'la Maududi, Dasar- dasar Islam, Bandung: Pustaka, 1997, hlm. 107

14 Syamsul Rijal Hamid, Buku Pintar Agama Islam(Edisi yang Disempurnakan), Bogor: CahayaSalam, 2008, hlm. 306 - 307

15 Ibid, 2

16 Nasruddin Razak, Dienullslam, (Bandung: PT AlMa'arif, 1989), hlm. 57 yang indah tanpa noda. Dalam kondisi seperti ini manusia akan menyadari betapa dangkalnya pengetahuan dan angan-angan manusia, sementara jauh direlung hatinya ia merasa bahwa dibalik setiap perkara dan fenomena terdapat sesuatu yang agung dan besar tiada tara" 17

\section{Macam-macam Ibadah}

Ibadah mencakup seluruh aktifitas manusia didalam semua bidang kehidupannya dan meliputi segala yang dicintai Allah dan diridhoi-Nya. Oleh karena itu, macam-macam ibadah ini dapat dibagi dengan bermacammacam cara. Seperti yang dikutip oleh Nasruddin Razak mengemukakan bahwa:

Ibadah ialah ber-taqarrub (mendekatkan diri) kepada Allah, dengan menaati segala perintah-Nya, menjauhi segala larangan-Nya dan mengamalkan segala yang diizinkan-Nya. Ibadah ada yang umum dan ada yang khusus:

a. Yang umum ialah segala amalan yang diizinkan Allah.

b. Yang $\boldsymbol{k h u s u s}$ ialah apa yang telah ditetapkan Allah akan perincian-perinciannya, tingkat dan cara-caranya yang tertentu. ${ }^{18}$

Para ulama membagi ibadah kepada:

a. Ibadah mahdhah, seperti iman, shalat, puasa, dan zakat.

b. Ibadah ghairu mahdhah, seperti kaffarat. ${ }^{19}$

Di dalam buku yang berjudul Ibadah dan Akhlak dalam Islam dijelaskan bahwa secara garis besar ibadah dibagi menjadi dua macam:

a. Ibadah Mahdhoh, yaitu ibadah yang macam dan cara pelaksanaannya ditentukan dalam syara' (ditentukan oleh Allah swt dan Muhammad saw). Ibadah mahdhoh ini bersifat tetap dan mutlak, manusia tinggal melaksanakan sesuai dengan peraturan dan tuntunan yang ada, seperti sholat, puasa, zakat, dan ibadah haji.

\footnotetext{
17 Ibid, hlm. 12

18 Nasruddin Razak, Dienullslam, hlm. 61

19 Tengku Muhammad Hasbi Ash Shiddieqy, Kuliahlbadah, hlm. 6
} 
b. Ibadah Ghairu Mahdhoh, yakni ibadah yang mencakup segala perbuatan, perkataan yang mendatangkan kebaikan dan dilaksanakan dengan niat yang ikhlas karena Allah swt dan ini banyak berkaitan dengan manusia lainnya.

\section{Upaya Guru Pendidikan Agama Islam dalam Meningkatan Kesadaran Beribadah Siswa}

Mengajar sebenarnya merupakan suatu proses transfer of knowledge. Artinya guru sebagai pengajar (mu'allim), bertugas mengajarkan berbagai macam ilmu pengetahuan kepada peserta didik, sehingga peserta didik mengerti, memahami, menghayati dan dapat mengamalkan berbagai ilmu pengetahuan tersebut. Guru juga berperan sebagai pendidik (muaddib), yang berusaha membentuk budi pekerti yang baik (akhlakulkarimah), pembentuk nilai-nilai (transferofvalues). Selain itu guru juga berperan untuk menularkan keterampilan, serta mengembangkan semua potensi peserta didik semaksimal mungkin. ${ }^{20}$

\section{Temuan Penelitian}

Setelah peneliti melakukan penelitian di SMPN 1 Banyakan Kab. Kediri, dapat di paparkan beberapa temuan penelitian sebagai berikut :

\section{Kesadaran Beribadah Siswa di SMN 1 Banyakan Kab. Kediri}

Kesadaran beribadah siswa di SMPN 1 Banyakan Kab. Kediri mayoritas sudah baik, hal ini dapat diketahui dengan mengamati kegiatan ibadah siswa, para siswa rajin dan aktif serta terlihat jelas bahwa sebagian besar siswa antusias melaksanakan ibadah. Setelah bel berbunyi siswa-siswa segera mengambil air wudhu dan shalat berjama'ah, sampai-sampai shalat dhuhur tidak hanya dilaksanakan 1 kali saja, melainkan beberapa kali dengan imam dari guru dan murid, karena jumlah siswa yang

20 Chabib Thoha, Metodologi Pengajaran Agama, (Semarang: Fakultas Tarbiyah IAIN Walosongo, 2004), hlm. 173 banyak sehingga tidak dimungkinkan untuk melaksanakan shalat dhuhur berjamaah hanya 1 (satu) kali (satu angkatan) saja.

Kemudian hal-hal yang mempengaruhi timbulnya kesadaran pada diri siswa dalam melaksanakan ibadah antara lain:

1. Kesadaran pribadi, artinya bahwa kemauan siswa dalam melaksanakan ibadah itu timbul dari dalam diri siswa, ia mengetahui bahwa ibadah suatu kewajiban dan kebutuhan bagi diri mereka.

2. Faktor teman, bagi siswa yang berteman dengan siswa yang rajin ke masjid untuk shalat akhirnya mereka terbawa oleh temannya. Mereka diajak oleh teman dan akan malu dengan sendirinya kalau tidak melaksanakan.

3. Faktor Lingkungan:

a. Lingkungan keluarga, rata-rata siswa yang berasal dari keluarga yang basik pendidikan agamanya kuat, menjadi pribadi yang baik di sekolah, mereka patuh, sopan, apabila bertemu dengan guru salam dan menjabat tangan, juga mereka rajin melaksanakan ibadah.

b. Lingkungan sekolah, salah satu faktor yang mempengaruhi kesadaran beribadah siswa adalah lingkungan sekolah. Di sekolah siswa tidak hanya diberi pengajaran yang bersifat umum saja tetapi juga harus diberi pengajaran yang bersifat kepada pendekatan kepada Tuhan Yang Maha Esa. Oleh karena itu di sekolah diadakan berbagai kegiatan keagamaan dan kegiatan yang lebih ditekankan pada praktik amaliyah seperti : bersalam-salaman dan salam, shalat Dhuha dan Dhuhur, shalat Jum'at, Infak, Pondok Ramadhan, praktek manasik Haji, penyembelihan hewan Qurban, dan sebagainya.

2. Upaya Guru Pendidikan Agama Islam dalam Meningkatkan Kesadaran Beribadah Siswa di SMPN 1 Banyakan Kediri 


\section{a. Keteladanan}

Keteladanan merupakan metode yang paling efektif dalam pendidikan. Semuanya dimulai dari gurunya terlebih dahulu baru siswanya, diharapkan guru dapat menjadi contoh (teladan) yang baik. Yang patut dicontoh adalah bapak Kepala sekolah, kemudian yang menjadi teladan tidak hanya guru PAI saja akan tetapi juga semua civitas akademik yang ada di SMPN 1 Banyakan Kab. Kediri.

\section{b. Pembiasaan}

Dengan cara diabsen, absensi diberikan kepada guru agama masing-masing, kemudian setelah berjalan dirubah ke kelas masing-masing, walaupun pada awalnya yang membuat absensi dan yang merekap bapak Anis Wahyudi sendiri.

c. Mengingatkan siswa menjelang waktu istirahat danmengopyak-opyak

Ketika bel berbunyi, langsung disampaikan lewat microfon untuk segera melaksanakan ibadah sesuai dengan agama masingmasing. Kemudian setelah itu baru mengopyak-ngopyakapabila ada siswa yang masih di kelas ketika waktu shalat.

\section{d. Memberi Nasehat}

Pada saat masuk kelas apabila ada absensi shalat dari siswa yang jarang atau bahkan kurang, maka diberi nasehat berhubungan dengan shalat tersebut. Pemberian nasehat tersebut lebih kepada pengetahuan dan pengertian mengenai pentingnya suatu ibadah, baik manfaat shalat, puasa, zakat, dan lain sebagainya.

\section{e. Memberi motivasi kepada siswa}

Misalnya siapa yang shalat dhuha maupun shalat dhuhurnya genap berapa kali, maka akan mendapat point dan nilai tambah, begitupun bagi yang mau mengabsen temannya, karena ia yang memegang amanat dan bertanggung jawab untuk berlaku jujur. Dengan sarana absensi dengan maksud bagaimana agar siswa mau melaksanakan kegiatan ibadah di sekolah, sehingga menjadi suatu kebiasaan.

f. Menciptakan suasana yang religius di

\section{sekolah}

Program tersebut terlihat mencolok sejak diadakannya Jum'at Religi, bagaimana menciptakan suasana religius di sekolah. Yaitu dengan cara antara lain yang pertama dengan mengadakan program shalat Dhuha, shalat Dhuhur, dan shalat Jum'at bersalamsalaman dan berjabat tangan infaq dan kotak amal, mengadakan bakti sosial, Idhul Adha dan Qurban, shalat Tarawih, Zakat Fitrah, Kantin "Kejujuran" yang memiliki tujuan untuk melatih siswa bersikap jujur, dan lain sebagainya.

g. Pendekatan Personal \& Fungsional kepada Siswa

Yaitu pendekatan secara personal, yaitu dengan memberikan pengertian bahwa ibadah merupakan kebutuhan mereka sendiri. Kemudian dengan pendekatan fungsional, yaitu memberikan pengetahuan kepada murid-murid bahwa orang-orang yang dekat dengan Allah adalah orangorang yang berhasil, misalnya orang-orang yang lulus dengan baik menjadi sarjana karena usaha dan ibadahnya.

1. Faktor Penghambat

1. Kesadaran siswa yang beragam, tidak semua siswa memiliki kesadaran yang baik dalam melaksanakan ibadah.

2. Waktu, Karena shalat dhuha dan shalat dhuhur dilaksanakan bertepatan dengan jam istirahat yaitu istirahat pertama selama 45 menit dari pukul 09.45-10.30 dan istirahat kedua mulai pukul 12.30-13.30, ada beberapa siswa yang lebih memilih untuk jajan di kantin daripada melaksanakan ibadah. Hal tersebut mereka lakukan dengan berbagai alasan, salah satunya karena lapar dan waktu istirahatnya cuma sebentar.

\section{A. Kesimpulan}

Setelah penulis melakukan penelitian tentang Upaya Guru Pendidikan Agama Islam (PAI) dalam Meningkatkan Kesadaran Beribadah di SMPN 1 Banyakan Kab. Kediri, 
Hasil penelitian ini memberikan penjelasan bahwa upaya guru pendidikan agama islam dalam meningkatkan kesadaran beribadah siswa di SMPN 1 Banyakan Kab. Kediri sangat beragama. Di antaranya dari unsur keteladanan, pembiasaan, memberikan motivasi, memberi nasehat dan mengajak secara langsung yang bersangkutan, dan menciptakan suasana yang religius di sekolah. Semua yang dilakukan di sekolah menggunakan pendekatan yang humanis. Sementara faktor Pendukung dan Penghambat bagi Guru Pendidikan Agama Islam dalam Upaya Meningkatkan Kesadaran Beribadah Pada Siswa di SMPN 1 Banyakan Kab. Kediri terdiri dari, kesadaran siswa sendiri, fasilitas ibadah yang cukup memaadahi, koordinasi yang baik dengan berbagai pihak, salah satu ekstra kurikuler, yaitu Sejarah Kebudayaan Islam (SKI). Kemudian faktor penghambat meliputi, kelengkapan sarana \& prasarana media pembelajaran praktek ibadah yang sangat minim, kesadaran siswa yang kompleks dan beragam, dan waktu pembelajaraan pendidikan agama Islam yang sangat terbatas.

\section{B. Saran-Saran}

Berdasarkan hasil penelitian di atas, melalui bab ini perlu di kemukakan saran-saran sebagai berikut:

1. Untuk menunjang pelaksanaan kegiatan beribadah siswa di sekolah diharapkan pihak sekolah dapat melengkapi sarana dan prasarana yang dibutuhkan sehingga pelaksanaan kegiatan ibadah bisa menjadi lebih baik dan maksimal.

2. Khusus untuk Guru Pendidikan Agama Islam dan seluruh Guru pada umumnya diharapkan mampu menjadi contoh dan teladan yang baik dalam beribadah, perilaku sehari-hari, tindak-taduknya dan ucapanya, sehingga tercipta kesadaran siswa dalam melaksanakan ibadah dengan baik dan benar.

3. Hendaknya ada koordinasi yang baik antara semua pihak yang terkait, baik pihak sekolah, orang tua wali murid, dan masyarakat, untuk mendukung semua kegiatan ibadah, baik di dalam maupun di luar sekolah.

\section{DAFTAR PUSTAKA}

Departemen Agama RI. 1984. Al-Qur'an dan Terjemahnya,. Proyek Pengadaan Kitab Suci al-Qur'an, t.tp.

A.K, H. Baihaqi, 1996.FiqihIbadah,Bandung: $\mathrm{M} 2 \mathrm{~S}$,

Aly, Hery Noer. 1999., Ilmu Pendidikan Islam, Jakarta: Logos.

-,Watak Pendidikan Islam, Jakarta: Friska Agung Insani, 2000.

Ash Shiddieqy, 2000. Tengku Muhammad Hasbi,KuliahIbadah (IbadahDitinjaudari SegiHukumdan Hikmah), Semarang: PT. Pustaka Rizki Putra.

Bayrak, SyekhTosun. danMurtadhaMuthahhari. , 2007. Energilbadah,Jakarta: PT Serambi Ilmu Semesta.

Darajat, Zakiyah. 1999.AgamaIslam. Jakarta: Bumi Aksara,

Departemen Agama RI. 2004..Al-Qur'an dan Terjemahnya,Edisi Baru, Surabaya: Tri Karya,

Djamarah, Syaiful Bahri, 2000.Guru dan Anak Didik dalam Interaktif Edukatif, Jakarta: Rineka Cipta,

Fauzi, Ahmad, 2004.Psikologi Umum, Bandung: Pustaka Setia,

Hadi, Sutrisno, 1990MetodologiReseacrh, Yogyakarta: Fakultas Psikologi UGM,

Hafidhudin,Didin, 1998. Panduan Praktis tentang Zakat, Infaq, Sedekah, Jakarta: Gema Insani,.

Hamid, Syamsul Rijal. 2008.,Buku Pintar Agama Islam(Edisi yang Disempurnakan), Bogor: Cahaya Salam,

Iskandar, 2015. Kesadaran, http://niasonline. net/2007/02/14/kesadaran/, diakses

Kamis, 3 Maret 2015

Mugni Labib, Konsep Kesadaran http:// getskripsi.com/2009/01/08/ 